\title{
When Does Ethical Leadership Affect Workplace Incivility? The Moderating Role of Follower Personality
}

\author{
Shannon G. Taylor \\ University of Central Florida
}

\author{
Marshall W. Pattie \\ James Madison University
}

\begin{abstract}
Although prior work has shown that employees with ethical leaders are less likely to engage in deviant or unethical behaviors, it is unknown whether all employees respond this way or to the same extent. Drawing on social learning theory as a conceptual framework, this study develops and tests hypotheses suggesting that two follower characteristics - conscientiousness and core self-evaluation-moderate the negative relationship between ethical leadership and workplace incivility. Data from employees of a U.S. public school district supported our predictions. Implications and future research directions are discussed.
\end{abstract}

KEY WORDS: conscientiousness, core self-evaluation, deviance, ethical leadership, ethics, workplace incivility

\begin{abstract}
A S THE CALAMITOUS EFFECTS OF RECENT SCANDALS have unfolded in business, government, and education, growing concerns among managers, regulators, academics, and the public at large have centered on ethical issues in organizational leadership. Not reserved solely for top corporate executives, increasing attention has been devoted to ethical leadership across organizational levels (Schaubroeck et al., 2012; Treviño, Brown, \& Hartman, 2003) and contexts (e.g., Resick, Martin, Keating, Dickson, Kwan, \& Peng, 2011). This growing interest is substantiated by recent research showing that the conduct of ethical leaders-i.e., those who demonstrate and promote normatively appropriate behavior through personal actions and decision-making, two-way communication, and reinforcement (Brown, Treviño, \& Harrison, 2005: 120)—can "trickle down" to affect the decision-making and behavior of employees at lower levels of the organization (e.g., Walumbwa, Mayer, Wang, Wang, Workman, \& Christensen, 2011). Moreover, and particularly germane to the present study, other work suggests employees with clear direction and reinforcement from ethical leaders are less likely to engage in unethical and deviant behaviors at work (Mawritz, Mayer, Hoobler, Wayne, \& Marinova, 2012; Mayer, Kuenzi, \& Greenbaum, 2010; Mayer, Kuenzi, Greenbaum, Bardes, $\&$ Salvador, 2009).
\end{abstract}


Among the types of deviant behaviors that cause harm to an organization or its members (Robinson \& Bennett, 1995), workplace incivility (Andersson \& Pearson, 1999; Blau \& Andersson, 2005) appears to be especially worthy of attention. Indeed, research exploring these rude and discourteous behaviors indicates that workplace incivility has become increasingly prevalent and cuts across a variety of industries. Incivility is believed to affect $98 \%$ of U.S. employees and to cost organizations millions of dollars annually (Porath \& Pearson, 2013). Given the important role leaders play in shaping employees' workplace attitudes and behavior, it appears imperative that leaders demonstrate, uphold, and reinforce interpersonal and organizational norms regarding appropriate workplace conduct to reduce the spread of workplace incivility.

However, past research attempting to link leader behavior, and ethical leadership in particular, to deviant employee behaviors has produced inconsistent results. Whereas some studies have found a negative relationship between ethical leadership and follower deviance, other work reports null relationships (cf. Detert, Treviño, Burris, \& Andiappan, 2007; Mayer et al., 2010). Intuitively, it seems reasonable to presume that only some - but not all-subordinates would emulate behaviors displayed by a leader, or that employees would respond to ethical leadership with varying degrees of acceptable and unacceptable (viz., uncivil) behavior. That prior work has focused on a group's shared perceptions of leaders may likewise contribute to results that diverge from expected relations between leadership and employee behavior at the individual level. While informative, studies adopting a group-level perspective fail to consider the possibility that perceptions of leadership or the resulting behaviors may vary substantially across followers. Nevertheless, such inconsistent findings suggest the presence of moderators, which identify conditions under which the link between ethical leadership and follower incivility may be more or less likely to hold. Supporting this idea, in a recent review Brown and Mitchell (2010) suggested potential boundary conditions of ethical leadership on inappropriate follower behavior. Among various possibilities, we suspect individual differences in followers' personality are one reason that can explain why employees might react differently to ethical leadership.

As such, the purpose of the present study is to better understand when ethical leadership will affect follower acts of workplace incivility. Our thinking is in line with previous research suggesting that follower personality traits can shape their reactions to interactions with leaders (e.g., Kamdar \& Van Dyne, 2007) and that certain subordinates are more or less likely to follow the behaviors of ethical leaders (Brown \& Treviño, 2006). By developing and testing hypotheses concerning the moderating role of two salient follower personality traits (i.e., conscientiousness and core self-evaluation, or CSE), we identify important boundary conditions that impact the effects of ethical leadership. In doing so, we seek to clarify previous results concerning the relationship between ethical leadership and follower deviance.

The present study makes three contributions to the business ethics and ethical leadership literatures. First, we link ethical leadership to workplace incivility, a prevalent and costly form of employee deviance. Whereas prior research has shown that followers may reduce their unethical or antisocial behaviors when working for ethical leaders, we expand this set of behavioral outcomes to include workplace 
incivility. This finding is important in that it provides a more fine-grained understanding of the connection between ethical leadership and workplace deviance. Second, we develop and test theoretically grounded predictions concerning the moderating role of follower personality traits. In establishing that followers' conscientiousness and CSE moderate their reactions to ethical leadership, we extend prior research by delineating conditions under which ethical leadership matters to a greater or lesser extent. Moreover, our study is one of the few to empirically demonstrate that followers' personality traits serve as boundary conditions on ethical leadership effects. Finally, the current study broadens the scope of ethical leadership research by investigating its impact in an academic context. Our results substantiate the general applicability of prior findings and address calls (Schaubroeck et al., 2012) to extend the generalizability of ethical leadership research by providing an even broader base for comparative analysis.

\section{THEORY AND HYPOTHESES}

\section{Ethical Leadership and Follower Incivility}

Several researchers have used social learning theory (Bandura, 1977, 1986) to explain the effects of ethical leadership on workplace outcomes (cf. Brown \& Mitchell, 2010). Brown and Treviño (2006) suggest social learning theory is similarly applicable in understanding negative outcomes of ethical leadership. Following prior studies examining the impact of ethical leadership on various follower misdeeds (e.g., Mayer et al., 2009, 2010), we employ this theoretical framework to explain why followers who work for ethical leaders should be less likely to engage in workplace incivility.

Social learning theory holds that individuals learn from rewards and punishments and through vicarious learning (Bandura, 1977, 1986). Ethical leaders can influence follower incivility through both mechanisms. Regarding the former, ethical leaders use rewards and punishments to hold followers accountable to ethical standards (Treviño et al., 2003). Consequences facilitate learning by apprising individuals of the benefits and costs associated with various behaviors deemed appropriate and inappropriate (Bandura, 1986; Brown et al., 2005). Thus, when followers learn that ethical conduct is rewarded and inappropriate conduct (e.g., incivility) is punished, they will be more likely to act accordingly (Brown et al., 2005; Treviño et al., 2003). Conversely, when inappropriate behavior goes unpunished or the consequences of violating the standards are unclear, followers are more likely to engage in normatively inappropriate behaviors such as incivility (Brown \& Treviño, 2006).

As for the latter mechanism, social learning theory suggests followers learn not only from their own rewards and punishments, but also by observing those experienced by others around them (Bandura, 1977, 1986). In this way, followers learn vicariously-i.e., they learn whether certain behaviors (e.g., incivility) are appropriate or not by witnessing or hearing about the consequences faced by other followers who have engaged in them (Mayer et al., 2009, 2010). It has been suggested that vicarious learning is particularly important when learning about deviant or unethical behavior (Brown \& Treviño, 2006; Brown et al., 2005). Thus, when a leader 
actively and explicitly communicates standards of workplace conduct and uses the organizational reward system to reinforce them, the leader's message is more likely to be salient in the work group and, thus, learned vicariously by followers (Bandura, 1986; Brown et al., 2005). Conversely, when followers witness others escape punishment or are otherwise "let off the hook" for misdeeds, it reinforces the notion that inappropriate behaviors such as workplace incivility will be tolerated. Based on the available literature and theoretical reasoning discussed above, we hypothesized:

Hypothesis 1. Ethical leadership will be negatively related to follower incivility.

\section{The Moderating Role of Personality}

Despite proposing a direct (negative) association between ethical leadership and follower incivility, we believe it is unlikely that all followers will respond to ethical leadership by reducing their uncivil behavior to the same extent. Rather, we suggest individual differences in follower personality will influence (i.e., moderate) their responses to ethical leadership. Although several personality traits might impact employee reactions to leader behaviors, conscientiousness and core self-evaluation are broad traits that partly reflect feelings of efficacy, the central mechanism motivating human behavior according to social learning theory (Bandura, 1977, 1986). Conscientiousness reflects tendencies to plan ahead, follow through, set high standards, and strive for excellence (Costa \& McCrae, 1992), whereas CSE refers to fundamental self-appraisals of one's worthiness and competence (Judge, Erez, Bono, \& Thoresen, 2003). As such, individuals higher in conscientiousness and CSE are confident in their capabilities and persevere when faced with difficulties. Such beliefs foster the motivation needed for "personal and social accomplishments" (Bandura, 1989: 1177), and constructive, effective actions that facilitate interpersonal relationships. Moreover, recent leadership research (Greenbaum, Mawritz, \& Eissa, 2012) suggests conscientiousness and CSE are particularly salient in determining how followers interact with and respond to leaders. Given their relevance to social learning (Bandura, 1977; Greenbaum et al., 2012), we offer theory-based predictions regarding the ways in which follower conscientiousness and CSE moderate the relationship between ethical leadership and follower incivility.

\section{Conscientiousness}

Conscientious individuals are responsible, disciplined, and dutiful. They are also known for being more reliable and sensible than their less conscientious counterparts (McCrae \& John, 1992). As Judge, Piccolo, and Kosalka (2009) observe, conscientious individuals "are detail-oriented, deliberate in their decision-making, and polite in most interpersonal interactions" (pp. 864-65). In contrast, individuals lower in conscientiousness tend to be careless and less likely to act in line with their conscience (McCrae \& John, 1992; Moon, 2001). As such, individuals lower in conscientiousness are more likely to engage in deviant behaviors such as incivility (Berry, Carpenter, $\&$ Barratt, 2012). With these characteristics in mind, we expected conscientiousness to influence the relationship between ethical leadership and follower incivility. 
Social learning theory supports the idea that conscientiousness could moderate the relationship between ethical leadership and follower incivility. Because followers higher in conscientiousness are less likely to engage in workplace incivility, one would expect that their interactions with leaders around this kind of behavior will be comparatively less frequent. That is, there would be less need for an ethical leader to interact with conscientious followers because they operate out of a strong sense of dutifulness and self-discipline (Costa \& McCrae, 1992). By contrast, followers lower in conscientiousness are more likely to commit acts of workplace incivility. Under these conditions, one might expect ethical leaders to act in response to the workplace incivility and to work more directly or closely with these followers. Consistent with social learning theory, ethical leadership is likely to be particularly relevant in deterring incivility in such instances, as ethical leaders discuss values with employees, clarify norms regarding appropriate workplace conduct, and discipline followers who violate these norms.

We further reasoned that conscientiousness would moderate the relationship between ethical leadership and follower incivility because of its association with integrity (e.g., Marcus, Hoft, \& Riediger, 2006). Conscientious individuals have high regard for moral duties and obligations (Walumbwa \& Schaubroeck, 2009) and are more likely to endorse and abide by ethical principles (Horn, Nelson, \& Brannick, 2004; McFerran, Aquino, \& Duffy, 2010). From a social learning perspective, this suggests they are more likely to treat people fairly and with respect on their own volition, and thus will have less need for an ethical leader to provide this sort of guidance. Conversely, less conscientious followers tend to lack integrity, suggesting they may be more likely to engage in incivility and more in need of a leader who will uphold norms regarding appropriate workplace behavior (Treviño, Hartman, \& Brown, 2000). Accordingly, we posit that when followers receive clear guidance from ethical leaders, those lower in conscientiousness are likely to reduce the frequency with which they engage in incivility to a greater extent than followers higher in conscientiousness (whose incivility levels are already relatively low). Thus, based on the theory and research discussed above, we hypothesized:

Hypothesis 2. Follower conscientiousness will moderate the relationship between ethical leadership and follower incivility, such that the negative relationship will be weaker when employees are high in conscientiousness.

\section{Core Self-Evaluation}

CSE (Judge, Locke, \& Durham, 1997) is a broad personality trait comprised of four narrower traits that reflect beliefs about one's ability to achieve desired outcomes (generalized self-efficacy), self-worth (self-esteem), tendency to be calm versus anxious (emotional stability), and perceived control of life events (locus of control). Meta-analysis has found higher CSE levels relate to improvements in motivation and performance and reductions in deviant work behaviors (Chang, Ferris, Johnson, Rosen, \& Tan, 2012). Moreover, high-CSE individuals believe they can successfully meet a wide variety of organizational demands, likely including those involving moral or ethical decision-making (Bandura, 1991; Zhu, Riggio, Avolio, \& Sosik, 
2011). We therefore expected CSE to influence the extent to which ethical leadership is associated with workplace incivility.

Given its connection with workplace deviance, we expected CSE would likewise moderate the relationship between ethical leadership and follower incivility. Because individuals lower in CSE have a greater tendency to engage in deviant work behaviors (Chang et al., 2012), there would be a greater need for an ethical leader to direct or oversee this type of follower. Consistent with social learning theory, efforts made by ethical leaders to communicate the importance of ethics and to set and enforce behavioral standards would go a long way toward reducing incivility among low-CSE followers (Bandura, 1986; Mayer et al., 2009, 2010). Conversely, because individuals higher in CSE approach work with confidence and feelings of internalized control, there is less need for an ethical leader to intervene. The effect of ethical leadership on workplace incivility is, thus, likely to be weaker among high-CSE followers.

Further supporting the proposed moderating effect of follower CSE is the idea that individuals higher in CSE and its core subtraits tend to rely on their own agency, whereas those with lower scores have less confidence in their own judgment (e.g., Greenbaum et al., 2012). Consistent with this logic, Hannah, Avolio, and May (2011) state that individuals lower in moral efficacy, a component of one's self concept, may fail to do the right thing (e.g., act ethically) because they lack the confidence to do so. In the same vein, other work suggests employees with lower self-efficacy and self-esteem are more likely to look to others (e.g., leaders) for guidance, intimating that ethical leadership will have a greater effect in reducing deviant behaviors among these types of followers (Avey, Palanski, \& Walumbwa, 2011; Chen, Gully, \& Eden, 2001). As CSE levels can affect the extent to which leader behavior impacts social learning and, consequently, a variety of work behaviors more broadly (e.g., see Judge \& Kammeyer-Mueller, 2011; Kacmar, Collins, Harris, \& Judge, 2009), we anticipated that CSE would similarly influence the relationship between ethical leadership and workplace incivility in particular. Specifically, we expected the effect of ethical leadership to be stronger among low-CSE followers and relatively weaker for followers with higher CSE levels. Accordingly, we hypothesized:

Hypothesis 3. Follower CSE will moderate the relationship between ethical leadership and follower incivility, such that the negative relationship will be weaker when employees are high in CSE.

\section{METHOD}

\section{Participants and Procedures}

The sample was comprised of teachers (63\%) and staff (e.g., counselors, maintenance, food service workers, clerical and administrative personnel, etc.) of a public school district in the eastern United States. Studying ethical leadership in the academic context is informative because leaders (i.e., principals) have a great degree of discretion in running their respective schools, and research suggests their actions 
can directly influence workplace incivility (Twale \& DeLuca, 2008). It should also be noted that leaders' effects on teachers can ultimately impact student learning outcomes and behavior (e.g., Stronge, 2007). Moreover, educational settings possess features that contribute to workplace incivility in other professional contexts (e.g., organizational pressures, technological changes, inferior leadership, norms for mutual respect; see Caza \& Cortina, 2007; Marchiondo, Marchiondo, \& Lasiter, 2010; Pearson, Andersson, \& Porath, 2005).

Given the relational nature of our study constructs and their proposed interrelationships, it is important that followers in our sample actually had some level of interaction with their leaders. Although we did not collect any data that speaks directly to teacher-principal interaction, we determined in pre-survey interviews with sample members (principals, teachers, and other employees) and in discussions with HR directors that leader-follower interaction occurs at least weekly during the school year. Teachers and staff interact regularly with principals, whether formally during meetings or informally during breaks, before or after school hours, or during other school-related functions (e.g., parent-teacher conferences, school dances, etc.). Part of the responsibility of a principal is to tour the building, observe employees, and provide immediate feedback. More frequent interaction occurs whenever there is a need (e.g., disruptive student, upset parent), and interaction is also higher at the beginning and end of this period due to the work required to launch and wrap up the school year. Thus, we have no reason to suspect that teachers interact with principals any less frequently than do other employees. ${ }^{1}$

The school district's human resources department provided the email addresses of all faculty and staff. Before the survey was distributed, school administrators (i.e., top management) sent an email to describe the study's purpose and encourage participation. We then sent sample members an email containing a link to our online survey; follow-up reminder emails were sent two and four weeks later. Of the 979 sample members contacted, 485 (49.5\%) supplied usable data. Respondents averaged $41(S D=11.3)$ years of age, and a majority was female $(81 \%)$ and held a bachelor's degree or higher $(85 \%)$.

\section{Measures}

Scores for all measures were computed by averaging across items, with higher scores indicating higher levels of the variable measured. Items for all measures appear in the Appendix.

Ethical Leadership

We assessed ethical leadership with Brown et al.'s (2005) ten-item measure. Respondents indicated how likely ( $1=$ highly unlikely; $5=$ highly likely) their principal was to engage in each leader behavior. Alpha reliability was .95 .

Follower Incivility

Employees indicated the frequency ( $1=$ never; 5 = about once a day) with which they engaged in uncivil behavior during the past year at work with a seven-item measure from Blau and Andersson (2005). Alpha reliability was .85. 


\section{Conscientiousness}

Conscientiousness was gauged with a ten-item measure from the International Personality Item Pool (IPIP; Goldberg et al., 2006). Respondents indicated how accurately $(1=$ very inaccurate $; 5=$ very accurate $)$ each item described them. Alpha reliability was .70 .

\section{Core Self-Evaluation}

We measured CSE with Judge et al.'s (2003) twelve-item measure. Respondents indicated the extent of agreement ( 1 = strongly disagree; 5 = strongly agree $)$ with each item. Alpha reliability was .82 .

\section{Control Variables}

We controlled for subordinate age, gender, and race because these characteristics have been shown to influence employee deviance (e.g., Mawritz et al., 2012). We also controlled for overall job satisfaction with a single item ("Overall, I am satisfied with my job") because of its relation with employee deviance (e.g., Dalal, 2005). Although such job satisfaction measures are conventionally avoided, Wanous, Reichers, and Hudy (1997: 250) maintain that "single-item measures are more robust than the scale measures of overall job satisfaction" (see also Nagy, 2002; Scarpello \& Hayton, 2001). Its correlation with other study measures was consistent with those found in prior research (e.g., Avey, Wernsing, \& Palanski, 2012; Chang et al., 2012), further supporting the measure's validity. We also controlled for emotional exhaustion (using a five-item measure $[\alpha=.88]$ adapted from Witt, Andrews, \& Carlson, 2004) to rule out the possibility that employees engaged in incivility because they were emotionally drained from their work (Blau \& Andersson, 2005). Finally, because respondents were located within a relatively small number $(k=11)$ of schools, we employed the fixed effects approach to clustering (Cohen, Cohen, West, \& Aiken, 2003) by creating and including ten dummy variables in analyses to account for potential nonindependence due to school membership. Including these dummy variables as covariates accounted for unmeasured differences between principals and schools by partialing out these effects from estimates of the coefficients and standard errors in the model (see Hayes, 2013).

\section{Data Analyses}

We tested our hypotheses using moderated regression analyses with mean-centered predictor variables. Control variables were entered in the first step, ethical leadership second, the moderators third, and each focal interaction term in a final step. Because both moderator variables were included in the third step simultaneously, the effects of each interaction can be interpreted as independent of or controlling for the main effect of the other moderator. To illustrate the form of the interactions, we plotted the effects at values one standard deviation above and below the mean of each moderator variable and conducted simple slope analyses as prescribed by Aiken and West (1991). 


\section{RESULTS}

\section{Preliminary Analyses}

Before testing our hypotheses, we conducted confirmatory factor analyses to evaluate the discriminant validity of the study variables (see Table 1). The results of a five-variable model (ethical leadership, follower incivility, conscientiousness, core self-evaluation, emotional exhaustion) revealed acceptable fit to the data and a significantly better fit $(p<.05)$ than alternative models in which the focal study constructs were variously combined. We also assessed discriminant validity by ensuring that the variance accounted for by each construct's items was greater than the variance shared between that construct and any other. As seen in Table 2, results from this analysis indicated adequate discriminant validity (Fornell \& Larcker, 1981; see also Netemeyer, Bearden, \& Sharma, 2003).

Although it has been argued that method bias cannot inflate interaction effects (Siemsen, Roth, \& Oliveira, 2010), we nonetheless examined common method variance issues in our data with Harman's single-factor test. To do so, we entered the study variable items into an exploratory factor analysis using unrotated principle component analysis. The emergence of a single factor or one that accounts for more than $25 \%$ of the total item variance suggests a problematic amount of same source bias (Williams, Cote, \& Buckley, 1989). The results of the analysis revealed the presence of multiple factors with eigenvalues greater than 1.0 and that no more than $19.75 \%$ of the total variance was explained by one factor. Given the presence of multiple distinct factors and that one factor did not explain a majority of the total variance, it is unlikely that same source bias is confounding our results.

Table 1: Confirmatory Factor Analyses

\begin{tabular}{lcccccc}
\hline \multicolumn{1}{c}{ Model } & $\boldsymbol{\chi}^{2}$ & $\boldsymbol{\Delta} \boldsymbol{\chi}^{2}$ & $\mathbf{d f}$ & CFI & RMSEA & SRMR \\
\hline 1. 5-factor expected model & 2694 & -- & 892 & 0.94 & 0.060 & 0.054 \\
2. 4-factor model: EL and FI combined & 5307 & $2613 *$ & 896 & 0.89 & 0.094 & 0.091 \\
3. 4-factor model: EL and CON combined & 4826 & $2132 *$ & 896 & 0.90 & 0.089 & 0.091 \\
4. 4-factor model: EL and CSE combined & 5725 & $3031 *$ & 896 & 0.89 & 0.098 & 0.100 \\
5. 4-factor model: EL and EE combined & 4845 & $2151 *$ & 896 & 0.89 & 0.089 & 0.091 \\
6. 4-factor model: FI and CON combined & 4753 & $2059 *$ & 896 & 0.90 & 0.088 & 0.087 \\
7. 4-factor model: FI and CSE combined & 5728 & $3034 *$ & 896 & 0.89 & 0.098 & 0.097 \\
8. 4-factor model: FI and EE combined & 4794 & $2100 *$ & 896 & 0.89 & 0.088 & 0.086 \\
9. 4-factor model: CON and CSE combined & 4141 & $1447 *$ & 896 & 0.91 & 0.080 & 0.071 \\
10. 4-factor model: CON and EE combined & 5063 & $2369 *$ & 896 & 0.89 & 0.091 & 0.081 \\
11. 4-factor model: CSE and EE combined & 4781 & $2087 *$ & 896 & 0.90 & 0.088 & 0.073 \\
\hline
\end{tabular}

Note: Model 1 includes ethical leadership (EL), follower incivility (FI), conscientiousness (CON), core selfevaluation (CSE), and emotional exhaustion (EE). CFI = comparative fit index, RMSEA = root mean square error of approximation, SRMR = standardized root mean square residual.

$* p<.05$ 


\section{Hypothesis Tests}

Means, standard deviations, and bivariate correlations for all study variables appear in Table 2. As expected, ethical leadership was negatively correlated $(r=-.15, p$ $<.001$ ) with follower incivility. Of the control variables, only job satisfaction and emotional exhaustion were associated with follower incivility. Consistent with past research (e.g., Blau \& Andersson, 2005), exhausted and dissatisfied respondents were more likely to report engaging in workplace incivility $(r=.17$ and -.17 , respectively, $p<.001)$ than their less exhausted, more satisfied counterparts.

Regression results are reported in Table 3. Hypothesis 1 proposed that ethical leadership would be negatively related to follower incivility. After accounting for the control variables (including the dummy variables for school location, none of which had any impact on prediction) in model 1, the entry of ethical leadership in model 2 resulted in a significant main effect. As shown in the table, ethical leadership was negatively related to follower incivility $(\beta=-.12, p<.05)$. In subsequent models with the moderators and interaction terms entered, however, ethical leadership was not significant. These results provide some support for Hypothesis 1. Consistent with Hypothesis 2 that conscientiousness would moderate the relationship between ethical leadership and follower incivility, the results of the last step of the regression show a significant interaction effect (model $4, \beta=.11, p<.05$ ). As illustrated in Figure 1 (panel a), the negative relationship between ethical leadership and workplace incivility was significant for followers with lower levels of conscientiousness (simple slope $=-.09, p<.05$ ) but not for more conscientious followers (

Hypothesis 3 posited that CSE would similarly moderate the relationship between ethical leadership and follower incivility. Consistent with our expectations, Table 3 illustrates that ethical leadership and CSE interacted to predict follower incivility (model 5, $\beta=.11, p<.05$ ). Figure 1 (panel b) shows that the negative relationship

Table 2: Descriptive Statistics and Intercorrelations among Study Variables

\begin{tabular}{|c|c|c|c|c|c|c|c|c|c|c|c|}
\hline & Variable & $\mathbf{M}$ & SD & 1 & 2 & 3 & 4 & 5 & 6 & 7 & 8 \\
\hline 1 & Ethical leadership & 4.04 & 0.84 & $(.81)$ & & & & & & & \\
\hline 2 & Follower incivility & 1.34 & 0.44 & $-.15^{* * *}$ & $(.70)$ & & & & & & \\
\hline 3 & Conscientiousness & 4.01 & 0.47 & .09 & $-.13 * *$ & $(.54)$ & & & & & \\
\hline 4 & CSE & 3.74 & 0.51 & $.21 * * *$ & $-.23 * * *$ & $.28 * * *$ & $(.54)$ & & & & \\
\hline 5 & Exhaustion & 2.72 & 0.94 & -.06 & $.17 * * *$ & -.07 & $-.35 * * *$ & $(.77)$ & & & \\
\hline 6 & Job satisfaction & 3.44 & 1.00 & $.43 * * *$ & $-.17 * * *$ & .06 & $.33 * * *$ & $-.29 * * *$ & -- & & \\
\hline 7 & Age & 41.45 & 11.28 & -.09 & .02 & .08 & $.10 *$ & $-.11 *$ & .07 & -- & \\
\hline 8 & Gender & 0.19 & 0.40 & .00 & .06 & $-.18 * * *$ & .03 & $.10^{*}$ & .02 & .03 & -- \\
\hline 9 & Race & 0.99 & 0.09 & .06 & -.04 & -.05 & .02 & .00 & -.03 & .02 & .05 \\
\hline
\end{tabular}

Note: $N=485$. Numbers in parentheses are the square root of the average variance explained, which, to demonstrate discriminant validity, must be larger than all correlations in the row and column in which they appear (Fornell \& Larcker, 1981). Gender was coded $0=$ female, $1=$ male. Race was coded $0=$ Non-white, $1=$ White.

$* p<.05 ; * * p<.01, * * * p<.001$ 
was significant for followers with lower levels of CSE (simple slope $=-.08, p<.05$ ) but not for those with higher CSE (simple slope $=.01, n . s$.$) . These results support$ Hypothesis 3.

Table 3: Hierarchical Regression Results

\begin{tabular}{|c|c|c|c|c|c|}
\hline Predictor & 1 & 2 & 3 & 4 & 5 \\
\hline \multicolumn{6}{|l|}{ Controls } \\
\hline Age & .04 & .03 & .04 & .04 & .04 \\
\hline Gender & .06 & .06 & .05 & .05 & .06 \\
\hline Race & -.04 & -.03 & -.04 & -.04 & -.03 \\
\hline Job satisfaction & $-.13 * *$ & -.08 & -.05 & -.06 & -.06 \\
\hline Emotional exhaustion & $.13^{* *}$ & $.14 * *$ & .09 & .08 & .09 \\
\hline School 1 & .04 & .04 & .04 & .03 & .03 \\
\hline School 2 & -.09 & -.09 & -.08 & -.08 & -.08 \\
\hline School 3 & -.03 & -.03 & -.02 & -.03 & -.04 \\
\hline School 4 & .03 & .05 & .06 & .05 & .05 \\
\hline School 5 & -.06 & -.07 & -.06 & -.06 & -.06 \\
\hline School 6 & -.05 & -.05 & -.03 & -.03 & -.03 \\
\hline School 7 & -.06 & -.07 & -.05 & -.05 & -.06 \\
\hline School 8 & .02 & .03 & .02 & .03 & .02 \\
\hline School 9 & .03 & .03 & .02 & .03 & .02 \\
\hline School 10 & .02 & .01 & .02 & .02 & .03 \\
\hline \multicolumn{6}{|l|}{ Main effect } \\
\hline Ethical leadership & & $-.12 *$ & -.09 & -.09 & -.07 \\
\hline \multicolumn{6}{|l|}{ Moderator } \\
\hline Conscientiousness & & & -.06 & -.08 & -.06 \\
\hline CSE & & & $-.15 * *$ & $-.14 * *$ & $-.17 * * *$ \\
\hline \multicolumn{6}{|l|}{ Interaction } \\
\hline Ethical leadership x Conscientiousness & & & & $.11^{*}$ & \\
\hline Ethical leadership x CSE & & & & & $.11 *$ \\
\hline Overall $F$ & 2.45 & 2.63 & 3.12 & 3.27 & 3.31 \\
\hline Total $R^{2}$ & $.07 * *$ & $.08 * * *$ & $.11 * * *$ & $.12 * * *$ & $.12 * * *$ \\
\hline$\Delta R^{2}$ & & $.01 *$ & $.03 * *$ & a $.01 *$ & ${ }^{\mathrm{a}} .01 *$ \\
\hline
\end{tabular}

Note. $N=485$. Standardized regression coefficients are reported. $\Delta R^{2}$ values may not sum exactly to $R^{2}$ values due to rounding.

$* p<.05 ; * * p<.01, * * * p<.001$

a. $\Delta R^{2}$ in relation to Model 3. 


\section{DISCUSSION}

The present study examined whether the negative relationship between ethical leadership and follower incivility was moderated by followers' personality traits (i.e., conscientiousness and core self-evaluation). In line with social learning theory, as well as previous research investigating the effects of ethical leadership (e.g., Mayer et al., 2009, 2010), we found that individuals who work for ethical leaders are less likely to engage in workplace incivility. Extending this line of research, we found that two follower personality traits affect this relationship. Specifically, we showed that the negative relationship between ethical leadership and follower incivility is
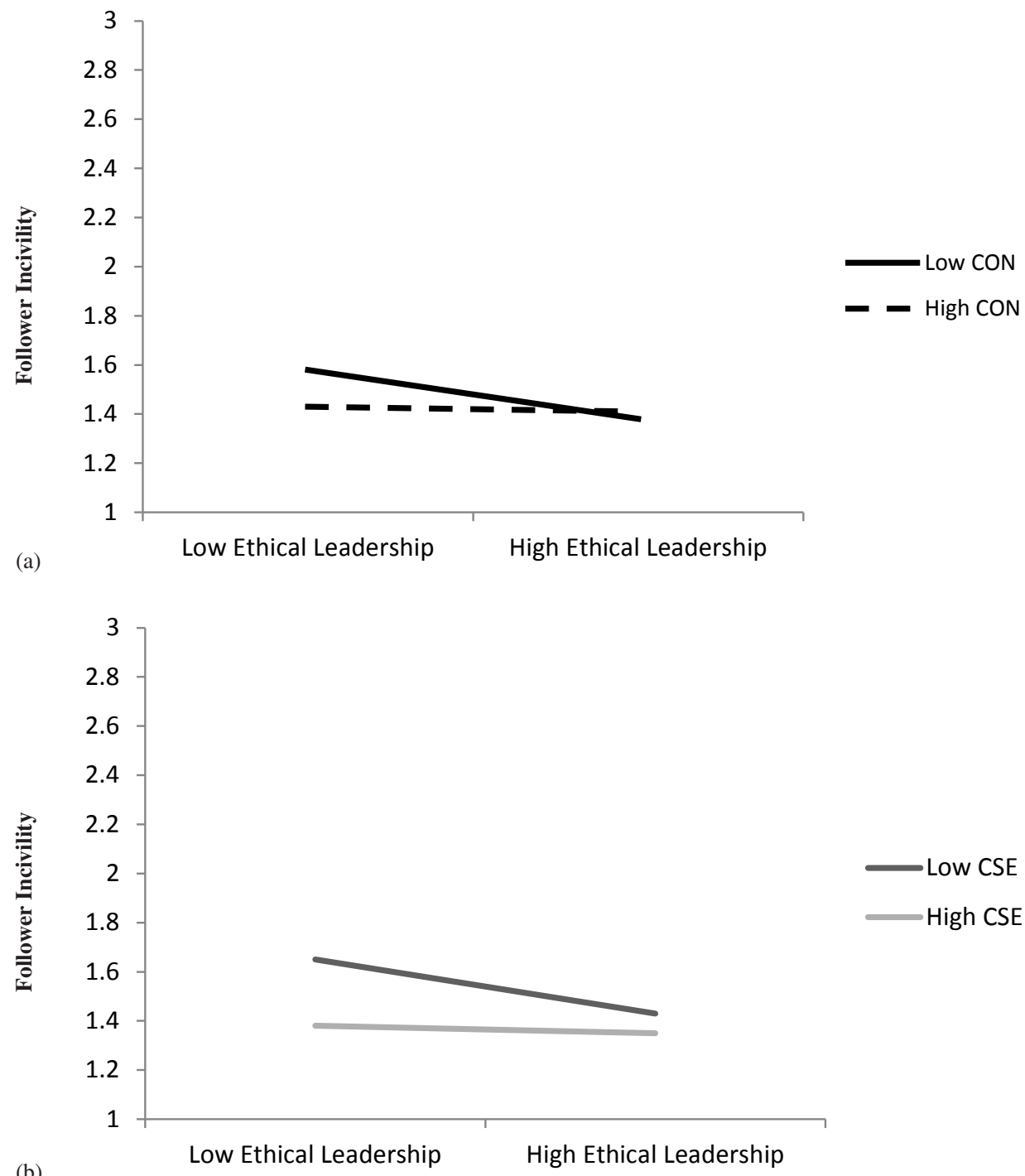

(b)

Figure 1. Note: Interactions of ethical leadership and subordinate personality on follower incivility. The negative relationship between ethical leadership and workplace incivility is significant for individuals with low but not high levels of conscientiousness (CON; panel a) and core self-evaluation (CSE; panel b). 
attenuated for followers with relatively higher levels of conscientiousness and core self-evaluations. In doing so, we identified conscientiousness and CSE as two follower personality traits that serve as important boundary conditions of the effects of ethical leadership.

These results are consistent with our social learning framework, as both the theory (Bandura, 1986) and related research (Twale \& DeLuca, 2008) suggest that learning processes are subject to individual differences. Yet closer inspection of Figure 1 suggests a more complex story. The interaction plots could be interpreted to indicate, for instance, that higher levels of conscientiousness and CSE can counteract low levels of ethical leadership and, alternatively, that higher levels of ethical leadership could neutralize the effects of these traits. Whereas researchers within the leadership domain have long observed that moderators can neutralize the effects of leaders' influence on employee behavior (e.g., Howell, Dorfman, \& Kerr, 1986), this alternative perspective positions follower personality traits as predictors of workplace incivility, and ethical leadership as a moderator of the personalityincivility relationship.

From this vantage, developing and testing theory positioning ethical leadership as a moderator of personality-incivility relations would be an interesting avenue for researchers to examine the complex and more nuanced ways in which ethical leadership and follower personality traits interact. For example, our results show that CSE was a stronger predictor of workplace incivility than was ethical leadership (cf. Avey et al., 2011). As such, continued investigations into potential neutralizers of leaders' effects on followers (e.g., Kamdar \& Van Dyne, 2007) may advance research examining the darker side of leader-follower interactions and aid in understanding followers' deviant behavior.

Although we found statistically significant results, the effect sizes observed in the present study were small. Ethical leadership contributed just one percent of additional variance beyond the control variables, as did the interaction terms beyond the main effects. However, small effects preclude neither theoretical nor practical importance (Aguinis, Gottfredson, \& Culpepper, 2013). As a reference point for comparison, the median effect size reported in Aguinis, Beaty, Boik, and Pierce's (2005) thirty-year review of moderating effects was .002. The small effects we observed should also be considered in light of the difficulty in explaining variance in deviant work outcomes (Zhang \& Shaw, 2012; see also Lee \& Allen, 2002). Thus, even so-called "weak" effects (according to Cohen's [1988] widely-cited conventions) can be important if they predict costly behaviors. Given the aforementioned costs associated with workplace incivility, we believe our findings have important practical implications.

\section{Practical Implications}

Broadly speaking, our results underscore the importance of investing in ethics and ethical leaders. Consistent with prior research, our findings suggest organizational efforts aimed at increasing ethical leadership can be helpful in reducing follower incivility. Such interventions are particularly important given that leaders' actions 
influence the behavior of employees at lower organizational levels (Walumbwa et al., 2011) and that workplace incivility can likewise spread throughout an organization (Pearson, Andersson, \& Porath, 2000). As such, we offer recommendations likely to resonate with organizational leaders and others concerned with ethical leadership and workplace incivility.

To the extent workplace incivility is an important concern in the school workplace, our study highlights how training efforts directed toward developing principals' ethical leadership skills can be of value. In educational settings, like other professional contexts, various organizational pressures have increased the potential for incivility in the workplace (e.g., Pearson \& Porath, 2005; Twale \& DeLuca, 2008). Nation-wide standards have been established for educational leaders to behave fairly and ethically when interacting with others (Council of Chief State School Officers, 2008), though it remains unclear whether principals receive effective training in this regard. Organizations could foster ethical leadership through interventions designed to develop leaders' moral reasoning, to promote role modeling with case studies (especially positive ones), or to coach related leadership skills (Brown \& Treviño, 2006). The implementation of such training programs for school principals and other organizational leaders could promote positive relationships and ultimately facilitate respectful, dignified (i.e., civil) treatment in the workplace (Pearson et al., 2000). Our results suggest it is important that organizations invest in the ethical training of leaders, in school settings and beyond.

\section{Limitations and Future Research}

Despite these empirical and practical implications, the present study is not without limitations that might be examined in future research. Our study could be extended to include a variety of different kinds of organizations. Another limitation is that we did not control for other individual variables-namely, moral identity and moral disengagement - that could have potentially affected followers' workplace incivility. Although we are aware of no research that has examined the effects of these variables on incivility, their impact on unethical behavior is well noted (e.g., Detert, Treviño, \& Sweitzer, 2008). As such, future research should likewise explore their associations with incivility and other deviant work behaviors.

Because our data were collected from a single source, it is possible that the observed relationships were influenced by common method variance (CMV; Podsakoff, MacKenzie, \& Podsakoff, 2012). To reduce method biases, we followed Podsakoff et al.'s (2012) recommendations to protect respondent anonymity and lessen evaluation apprehension. We also provided empirical evidence from Harman's single-factor test demonstrating that same source bias did not unduly impact our findings. In addition, Evans (1985) suggests interactions provide evidence against CMV, as it is unclear how common source or method effects would operate differently across levels of a moderator (see also Siemsen et al., 2010). Although recent meta-analytic evidence suggests self-reports are a viable means of assessing employee acts of deviance (Berry et al., 2012), future research could nonetheless collect perceptions of ethical 
leadership or incivility from other sources (e.g., peers, coworkers) to further reduce concerns about same-source effects.

Future studies may also wish to explore the impact that facet-level characteristics of conscientiousness or CSE have on the relationships we examined. For instance, conscientiousness facets may moderate the ethical leadership-incivility relationship in substantially different ways. Supporting this possibility, Griffin and Hesketh (2005) found that conscientiousness facets related to achievement (e.g., competence, self-discipline, achievement striving) were positively associated with adaptive behavior, whereas those related to dependability (e.g., order, dutifulness, cautiousness) were not (and in some cases, negatively) associated with such behavior (see also Marinova, Moon, \& Kamdar, 2013; Moon, 2001). Thus, as suggested by an anonymous reviewer, some aspects of conscientiousness (e.g., dutifulness, which reflects rule following) might actually strengthen (rather than weaken) the effect of ethical leadership on follower incivility. We encourage future researchers to explore these possibilities.

An additional opportunity for future research concerns whether other individual difference variables might also impact the relationship between ethical leadership and follower incivility. For example, a broad class of individual differences referred to as "character strengths" (Peterson \& Seligman, 2004)—-such as wisdom, courage, and temperance-have implications for individuals' moral thoughts and actions in a work setting (see, e.g., Comer \& Vega, 2011). Whereas these characteristics have been identified as important for leaders and their influence on follower behavior (Riggio, Zhu, Reina, \& Maroosis, 2010; Wright \& Quick, 2011), subsequent research efforts might explore the interplay of leader and follower virtues in affecting leaderfollower relations. One especially promising characteristic is behavioral integrity (i.e., consistency between words and actions; Simons, 2002), which has garnered considerable attention from ethics and leadership researchers. We suggest future endeavors consider these characteristics as additional boundary conditions on the relationship reported here to broaden understanding of workplace incivility in connection with ethical leadership.

In conclusion, the current study demonstrated that while, in general, followers tend to respond to ethical leadership by reducing the frequency with which they engage in workplace incivility, certain types of followers are more or less likely to do so. Specifically, we predicted and found that the negative link between ethical leadership and follower incivility is weaker when followers are high in conscientiousness or core self-evaluation. Despite the potential costs to individuals and organizations of workplace incivility, little research has attempted to understand how follower personality influences employees' deviant reactions to ethical leadership. As such, the present findings inform prior research by illustrating individual differences in conscientiousness and CSE can diminish the spread of uncivil behavior. 


\section{APPENDIX \\ ITEMS FOR ALL SURVEY MEASURES}

* indicates item was reverse-scored

\section{Ethical Leadership}

My supervisor ...

1. Listens to what employees have to say

2. Disciplines employees who violate ethical standards

3. Conducts his/her personal life in an ethical manner

4. Has the best interests of employees in mind

5. Makes fair and balanced decisions

6. Can be trusted

7. Discusses business ethics or values with employees

8. Sets an example of how to do things the right way in terms of ethics

9. Defines success not just by results but also the way they are obtained

10. When making decisions, asks "What is the right thing to do?"

\section{Workplace Incivility}

1. I put others down or was condescending to them.

2. I paid little attention to others' statements or showed little interest in their opinions.

3. I made demeaning or derogatory remarks about others.

4. I addressed others in unprofessional terms, either publicly or privately.

5. I ignored or excluded others from professional camaraderie.

6. I doubted others' judgment on a matter over which they had responsibility.

7. I made unwanted attempts to draw others into a discussion of personal matters.

\section{Conscientiousness}

1. I am always prepared.

2. I pay attention to details.

3. I get chores done right away.

4. I carry out my plans.

5. I make plans and stick to them.

6. I waste my time.*

7. I find it difficult to get down to work.*

8. I do just enough work to get by.*

9. I don't see things through.*

10. I shirk my duties.*

\section{Core Self-Evaluation}

1. I am confident I get the success I deserve in life.

2. Sometimes I feel depressed.*

3. When I try, I generally succeed.

4. Sometimes when I fail I feel worthless.*

5. I complete tasks successfully.

6. Sometimes, I do not feel in control of my work.*

7. Overall, I am satisfied with myself.

8. I am filled with doubts about my competence.*

9. I determine what will happen in my life.

10. I do not feel in control of my success in my career.*

11. I am capable of coping with most of my problems.

12. There are times when things look pretty bleak and hopeless to me.* 


\section{NOTES}

We thank Jerry Goodstein and three anonymous reviewers for their helpful comments and guidance on previous versions of this manuscript. In addition, we thank members of the UCF Behavioral Ethics Group for their valuable input and Craig D. Crossley for his helpful comments on an earlier draft manuscript. This work was partially supported by the Gilliam Center for Free Enterprise and Ethical Leadership, College of Business, James Madison University. Correspondence concerning this manuscript should be addressed to Shannon G. Taylor, Department of Management, University of Central Florida, P.O. Box 161400, Orlando, FL 32816-1400. Email may be sent to sgtaylor@ucf.edu.

1. As requested by an anonymous reviewer, we conducted a few supplementary analyses to determine whether participants' job type had any impact on our results. One-way ANOVAs revealed that teachers did not perceive their principals to be ethical leaders any more or less than did staff employees $(F=.098, n . s$. $)$, nor did they report engaging in any more or less workplace incivility than did other employees $(F=.066$, n.s.). Moreover, including a dichotomous variable $(1=$ teacher, $0=$ otherwise $)$ in the regression equations we estimated did not change the results of our hypothesis tests.

\section{REFERENCES}

Aguinis, H., Beaty, J. C., Boik, R. J., \& Pierce, C. A. 2005. Effect size and power in assessing moderating effects of categorical variables using multiple regression: A 30-year review. Journal of Applied Psychology, 90: 94-107.

http://dx.doi.org/10.1037/0021-9010.90.1.94

Aguinis, H., Gottfredson, R. K., \& Culpepper, S. A. 2013. Best-practice recommendations for estimating cross-level interaction effects using multilevel modeling. Journal of Management, 39(6): 1490-1528. http://dx.doi.org/10.1177/0149206313478188

Aiken, S. L., \& West, S. G. 1991. Multiple regression: Testing and interpreting interactions. Thousand Oaks, CA: Sage.

Andersson, L. M., \& Pearson, C. M. 1999. Tit for tat? The spiraling effect of incivility in the workplace. Academy of Management Review, 24: 452-71.

Avey, J. B., Palanski, M. E., \& Walumbwa, F. O. 2011. When leadership goes unnoticed: The moderating role of follower self-esteem on the relationship between ethical leadership and follower behavior. Journal of Business Ethics, 98: 573-82. http://dx.doi.org/10.1007/s10551-010-0610-2

Avey, J. B., Wernsing, T. S., \& Palanski, M. E. 2012. Exploring the process of ethical leadership: The mediating role of employee voice and psychological ownership. Journal of Business Ethics, 107: 21-34. http://dx.doi.org/10.1007/s10551-012-1298-2

Bandura, A. 1977. Social learning theory. Englewood Cliffs, NJ: Prentice-Hall.

1986. Social foundations of thought and action. Englewood Cliffs, NJ: Prentice-Hall.

1989. Human agency in social cognitive theory. American Psychologist, 44:

1175-84. http://dx.doi.org/10.1037/0003-066X.44.9.1175

1991. Social cognitive theory of moral thought and action. In W. M. Kurtines \& J. L. Gewirtz (Eds.), Handbook of moral behavior and development (Vol. 1, pp. 45-103). Hillsdale, NJ: Erlbaum. 
Berry, C. M., Carpenter, N. C., \& Barratt, C. L. 2012. Do other-reports of counterproductive work behavior provide an incremental contribution over self-reports? A metaanalytic comparison. Journal of Applied Psychology, 97: 613-36.

http://dx.doi.org/10.1037/a0026739

Blau, G., \& Andersson, L. 2005. Testing a measure of instigated workplace incivility. Journal of Occupational and Organizational Psychology, 78: 595-614. http://dx.doi.org/10.1348/096317905X26822

Brown, M. E., \& Mitchell, M. S. 2010. Ethical and unethical leadership: Exploring new avenues for future research. Business Ethics Quarterly, 20: 583-616. http://dx.doi.org/10.5840/beq201020439

Brown, M. E., \& Treviño, L. K. 2006. Ethical leadership: A review and future directions. Leadership Quarterly, 17: 595-616. http://dx.doi.org/10.1016/j.leaqua.2006.10.004

Brown, M. E., Treviño, L. K., \& Harrison, D. A. 2005. Ethical leadership: A social learning perspective for construct development and testing. Organizational Behavior and Human Decision Processes, 97: 117-34. http://dx.doi.org/10.1016/j.obhdp.2005.03.002

Caza, B. B., \& Cortina, L. M. 2007. From insult to injury: Explaining the impact of incivility. Basic and Applied Social Psychology, 29: 335-50.

http://dx.doi.org/10.1080/01973530701665108

Chang, C-H., Ferris, D. L., Johnson, R. E., Rosen, C. C., \& Tan, J. A. 2012. Core selfevaluations: A review and evaluation of the literature. Journal of Management, 38: 81-128. http://dx.doi.org/10.1177/0149206311419661

Chen, G., Gully, S. M., \& Eden, D. 2001. Validation of a new general self-efficacy scale. Organizational Research Methods, 4: 62-83.

http://dx.doi.org/10.1177/109442810141004

Cohen, J. 1988. Statistical power analysis for the behavioral sciences (2nd ed.). Hillsdale, NJ: Erlbaum.

Cohen, J., Cohen, P., West, S. G., \& Aiken, S. L. 2003. Applied multiple regression/correlation analysis for the behavioral sciences. Mahwah, NJ: Lawrence Erlbaum.

Comer, D. R., \& Vega, G. (Eds.). 2011. Moral courage in organizations: Doing the right thing at work. Armonk, NY: M. E. Sharp.

Costa, P. T., Jr., \& McCrae, R. R. 1992. Revised NEO Personality Inventory (NEO-PI-R) and the NEO Five-Factor (NEO-FFI) Inventory professional manual. Odessa, FL: Psychological Assessment Resources.

Council of Chief State School Officers. 2008. Educational leadership policy standards: ISLLC 2008. Washington, DC: Author.

Dalal, R. S. 2005. A meta-analysis of the relationship between organizational citizenship behavior and counterproductive work behavior. Journal of Applied Psychology, 90: 1241-55. http://dx.doi.org/10.1037/0021-9010.90.6.1241

Detert, J. R., Treviño, L. K., Burris, E. R., \& Andiappan, M. 2007. Managerial modes of influence and counterproductivity in organizations: A longitudinal business-unitlevel investigation. Journal of Applied Psychology, 92: 993-1005.

http://dx.doi.org/10.1037/0021-9010.92.4.993 
Detert, J. R., Treviño, L. K., \& Sweitzer, V. L. 2008. Moral disengagement in ethical decision making: A study of antecedents and outcomes. Journal of Applied Psychology, 93: 374-91. http://dx.doi.org/10.1037/0021-9010.93.2.374

Evans, M. G. 1985. A Monte Carlo study of the effects of correlated method variance in moderated multiple regression analysis. Organizational Behavior and Human Decision Processes, 36: 305-23. http://dx.doi.org/10.1016/0749-5978(85)90002-0

Fornell, C., \& Larcker, D. F. 1981. Evaluating structural equation models with unobservable variables and measurement error. Journal of Marketing Research, 18: 39-50. http://dx.doi.org/10.2307/3151312

Goldberg, L. R., Johnson, J. A., Eber, H. W., Hogan, R., Ashton, M. C., Cloninger, C. R., \& Gough, H. G. 2006. The International Personality Item Pool and the future of public-domain personality measures. Journal of Research in Personality, 40: 84-96. http://dx.doi.org/10.1016/j.jrp.2005.08.007

Greenbaum, R. L., Mawritz, M. B., \& Eissa, G. 2012. Bottom-line mentality as an antecedent of social undermining and the moderating roles of core self-evaluations and conscientiousness. Journal of Applied Psychology, 97: 343-59. http://dx.doi.org/10.1037/a0025217

Griffin, B., \& Hesketh, B. 2005. Are conscientious workers adaptable? Australian Journal of Management, 30: 245-59. http://dx.doi.org/10.1177/031289620503000204

Hannah, S. T., Avolio, B. J., \& May, D. R. 2011. Moral maturation and moral conation: A capacity approach to explaining moral thought and action. Academy of Management Review, 36: 663-85.

Hayes, A. F. 2013. Introduction to mediation, moderation, and conditional process analysis. New York: Guilford.

Horn, J., Nelson, C. E., \& Brannick, M. T. 2004. Integrity, conscientiousness, and honesty. Psychological Reports, 95: 27-38.

Howell, J. P., Dorfman, P. W., \& Kerr, S. 1986. Moderator variables in leadership research. Academy of Management Review, 11: 88-102.

Judge, T. A., Erez, A., Bono, J. E., \& Thoresen, C. J. 2003. The core self-evaluations scale: Development of a measure. Personnel Psychology, 56: 303-31. http://dx.doi.org/10.1111/j.1744-6570.2003.tb00152.x

Judge, T. A., \& Kammeyer-Mueller, J. D. 2011. Implications of core self-evaluations for a changing organizational context. Human Resource Management Review, 21: 331-41. http://dx.doi.org/10.1016/j.hrmr.2010.10.003

Judge, T. A., Locke, E. A., \& Durham, C. C. 1997. The dispositional causes of job satisfaction: A core evaluations approach. Research in Organizational Behavior, 19: 151-88.

Judge, T. A., Piccolo, R. F., \& Kosalka, T. 2009. The bright and dark sides of leader traits: A review and theoretical extension of the leader trait paradigm. Leadership Quarterly, 20: 855-75. http://dx.doi.org/10.1016/j.leaqua.2009.09.004

Kacmar, K. M., Collins, B. J., Harris, K. J., \& Judge, T. A. 2009. Core self-evaluations and job performance: The role of perceived work environment. Journal of Applied Psychology, 94: 1572-80. http://dx.doi.org/10.1037/a0017498 
Kamdar, D., \& Van Dyne, L. 2007. The joint effects of personality and workplace social exchange relationships in predicting task performance and citizenship performance. Journal of Applied Psychology, 92: 1286-98. http://dx.doi.org/10.1037/0021-9010.92.5.1286

Lee, K., \& Allen, N. J. 2002. Organizational citizenship behavior and workplace deviance: The role of affect and cognitions. Journal of Applied Psychology, 87: 131-42. http://dx.doi.org/10.1037/0021-9010.87.1.131

Marchiondo, K., Marchiondo, L. A., \& Lasiter, S. 2010. Faculty incivility: Effects on program satisfaction of BSN students. Journal of Nursing Education, 49: 608-14. http://dx.doi.org/10.3928/01484834-20100524-05

Marcus, B., Hoft, S., \& Riediger, M. 2006. Integrity tests and the five-factor model of personality: A review and empirical test of two alternative positions. International Journal of Selection and Assessment, 14: 113-20. http://dx.doi.org/10.1111/j.1468-2389.2006.00338.x

Marinova, S. V., Moon, H., \& Kamdar, D. 2013. Getting ahead or getting along? The twofacet conceptualization of conscientiousness and leadership emergence. Organization Science, 24: 1257-76. http://dx.doi.org/10.1287/orsc.1120.0781

Mawritz, M. B., Mayer, D. M., Hoobler, J. M., Wayne, S. J., \& Marinova, S. V. 2012. A trickle-down model of abusive supervision. Personnel Psychology, 65: 325-57. http://dx.doi.org/10.1111/j.1744-6570.2012.01246.x

Mayer, D. M., Kuenzi, M., Greenbaum, R., Bardes, M., \& Salvador, R. 2009. How does ethical leadership flow? Test of a trickle-down model. Organizational Behavior and Human Decision Processes, 108: 1-13.

http://dx.doi.org/10.1016/j.obhdp.2008.04.002

Mayer, D. M., Kuenzi, M., \& Greenbaum, R. L. 2010. Examining the link between ethical leadership and employee misconduct: The mediating role of ethical climate. Journal of Business Ethics, 95: 7-16. http://dx.doi.org/10.1007/s10551-011-0794-0

McCrae, R. R., \& John, O. P. 1992. An introduction to the five-factor model and its applications. Journal of Personality, 60: 175-215. http://dx.doi.org/10.1111/j.1467-6494.1992.tb00970.x

McFerran, B., Aquino, K., \& Duffy, M. 2010. How personality and moral identity relate to individuals' ethical ideology. Business Ethics Quarterly, 20: 35-56. http://dx.doi.org/10.5840/beq20102014

Moon, H. 2001. The two faces of conscientiousness: Duty and achievement striving in escalation of commitment dilemmas. Journal of Applied Psychology, 86: 533-40. http://dx.doi.org/10.1037/0021-9010.86.3.535

Nagy, M. S. 2002. Using a single-item approach to measure facet job satisfaction. Journal of Occupational and Organizational Psychology, 75: 77-86. http://dx.doi.org/10.1348/096317902167658

Netemeyer, R. G., Bearden, W. O., \& Sharma, S. 2003. Scaling procedures: Issues and applications. Thousand Oaks, CA: Sage.

Pearson, C. M., Andersson, L. M., \& Porath, C. L. 2000. Assessing and attacking workplace incivility. Organizational Dynamics, 29(2): 123-37.

http://dx.doi.org/10.1016/S0090-2616(00)00019-X 
2005. Workplace incivility. In S. Fox \& P. E. Spector (Eds.), Counterproductive work behavior: Investigations of actors and targets, 177-200). Washington, DC: American Psychological Association.

Pearson, C. M., \& Porath, C. L. 2005. On the nature, consequences and remedies of workplace incivility: No time for "nice"? Think again. Academy of Management Executive, 19: 7-18.

Peterson, C., \& Seligman, M. E. P. 2004. Character strengths and virtues: A handbook and classification. New York: Oxford.

Podsakoff, P. M., MacKenzie, S. B., \& Podsakoff, N. P. 2012. Sources of method bias in social science research and recommendations on how to control it. Annual Review of Psychology, 63: 539-69. http://dx.doi.org/10.1146/annurev-psych-120710-100452

Porath, C., \& Pearson, C. 2013. The price of incivility. Harvard Business Review, 91(1-2): 114-21.

Resick, C. J., Martin, G. S., Keating, M. A., Dickson, M. W., Kwan, H. K., \& Peng, C. 2011. What ethical leadership means to me: Asian, American, and European perspectives. Journal of Business Ethics, 101: 435-57.

http://dx.doi.org/10.1007/s10551-010-0730-8

Riggio, R. E., Zhu, W., Reina, C., \& Maroosis, J. A. 2010. Virtue-based measurement of ethical leadership: The Leadership Virtues Questionnaire. Consulting Psychology Journal: Practice and Research, 62: 235-50. http://dx.doi.org/10.1037/a0022286

Robinson, S. L., \& Bennett, R. J. 1995. A typology of deviant workplace behaviors: A multidimensional scaling study. Academy of Management Journal, 38: 555-72. http://dx.doi.org/10.2307/256693

Scarpello, V., \& Hayton, J. C. 2001. Identifying the sources of nonequivalence in measures of job satisfaction. In C. A. Schriesheim \& L. L. Neider (Eds.), Equivalence in measurement: 131-60. Greenwich, CT: Information Age.

Schaubroeck, J. M., Hannah, S. T., Avolio, B. J., Kozlowski, S. W. J., Lord, R. G., Treviño, L. K., Dimotakis, N., \& Peng, A. C. 2012. Embedding ethical leadership within and across organization levels. Academy of Management Journal, 55: 1053-78. http://dx.doi.org/10.5465/amj.2011.0064

Siemsen, E., Roth, A., \& Oliveira, P. 2010. Common method bias in regression models with linear, quadratic, and interaction effects. Organizational Research Methods, 13: 456-76. http://dx.doi.org/10.1177/1094428109351241

Simons, T. 2002. Behavioral integrity: The perceived alignment between managers' words and deeds as a research focus. Organization Science, 13: 18-35. http://dx.doi.org/10.1287/orsc.13.1.18.543

Stronge, J. H. 2007. Qualities of effective teachers (2nd ed.). Alexandria, VA: ASCD Publications.

Treviño, L. K., Brown, M., \& Hartman, L. P. 2003. A qualitative investigation of perceived executive ethical leadership: Perceptions from inside and outside the executive suite. Human Relations, 56: 5-37. http://dx.doi.org/10.1177/0018726703056001448

Treviño, L. K., Hartman, L. P., \& Brown, M. 2000. Moral person and moral manager: How executives develop a reputation for ethical leadership. California Management Review, 42(4): 128-42. http://dx.doi.org/10.2307/41166057 
Twale, D., \& DeLuca, B. 2008. Faculty incivility: The rise of the academic bully culture and what to do about it. San Francisco: Jossey-Bass.

Walumbwa, F. O., Mayer, D. M., Wang, P., Wang, H., Workman, K., \& Christensen, A. L. 2011. Linking ethical leadership to employee performance: The roles of leadermember exchange, self-efficacy, and organizational identification. Organizational Behavior and Human Decision Processes, 115: 204-13. http://dx.doi.org/10.1016/j.obhdp.2010.11.002

Walumbwa, F. O., \& Schaubroeck, J. 2009. Leader personality traits and employee voice behavior: Mediating roles of ethical leadership and work group psychological safety. Journal of Applied Psychology, 94: 1275-86. http://dx.doi.org/10.1037/a0015848

Wanous, J. P., Reichers, A. E., \& Hudy, M. J. 1997. Overall job satisfaction: How good are single-item measures? Journal of Applied Psychology, 82: 247-52. http://dx.doi.org/10.1037/0021-9010.82.2.247

Williams, L., Cote, J., \& Buckley, M. 1989. Lack of method variance in self-reported affect and perceptions of work: Reality or artifact? Journal of Applied Psychology, 74: 462-68. http://dx.doi.org/10.1037/0021-9010.74.3.462

Witt, L. A., Andrews, M. C., \& Carlson, D. S. 2004. When conscientiousness isn't enough: Emotional exhaustion and performance among call center customer service representatives. Journal of Management, 30: 149-60. http://dx.doi.org/10.1016/j.jm.2003.01.007

Wright, T. A., \& Quick, J. C. 2011. The role of character in ethical leadership research. Leadership Quarterly, 22: 975-78. http://dx.doi.org/10.1016/j.leaqua.2011.07.015

Zhang, Y. A., \& Shaw, J. D. 2012. Publishing in AMJ-part 5: Crafting the methods and results. Academy of Management Journal, 55: 8-12. http://dx.doi.org/10.5465/amj.2012.4001

Zhu, W., Riggio, R. E., Avolio, B. J., \& Sosik, J. J. 2011. The effect of leadership on follower moral identity: Does transformational/transactional style make a difference? Journal of Leadership and Organizational Studies, 18: 150-63. http://dx.doi.org/10.1177/1548051810396714 